Mini Review

\title{
Induction of Th17 cells by dendritic cells
}

\author{
Sanju Iwamoto ${ }^{1, *)}$, Shin-ichi Iwai²), Katsuji Oguchi²), \\ Hajime Yasuhara ${ }^{3)}$, and Akira Miyazaki ${ }^{11}$ \\ ${ }^{1)}$ Department of Biochemistry, Showa University School of Medicine, Tokyo, Japan \\ 2)1st Department of Pharmacology, Showa University School of Medicine, Tokyo, Japan \\ ${ }^{3)}$ 2st Department of Pharmacology, Showa University School of Medicine, Tokyo, Japan
}

\begin{abstract}
The novel Thelper subset, Th17, plays a critical role in the pathogenesis of a variety of chronic inflammatory disorders such as rheumatoid arthritis, Crohn's disease, and others. Although inflammatory dendritic cells (DCs), such as DCs producing TNF $\alpha$ and iNOS, have been suggested to act as an inducer of Th17immunity both in humans and mice in vivo; it is unclear how DCs elicit Th17-immunity. Recently, some Th17differentiation pathways, both TGF- $\beta$-dependent and -independent pathways, have been identified in mice. However, the DC biology to evoke Th17-immunity in chronic inflammation or autoimmunity has not yet been clarified, in particular, in human cells. This review summarizes and discusses the induction of Th17 cells by DCs.
\end{abstract}

Rec.10/20/2009, Acc.3/3/2010, pp440-444

\begin{abstract}
* Correspondence should be addressed to:
Sanju Iwamoto, Department of Biochemistry, Showa University School of Medicine, 1-5-8 Hatanodai, Shinagawa-ku, Tokyo 142-8555, Japan. Phone: +81-3-3874-8116, Fax: +81-3-3784-2346, e-mail: iwasanju@med.showa-u.ac.jp
\end{abstract}

Key words inflammatory DCs, Th17, TGF- $\beta$, IL-1, IL-23

\section{Introduction}

Dendritic cells (DCs) are multifunctional professional antigen-presenting cells ${ }^{1}$. A subset of DC, inflammatory DC, is recruited into inflamed tissue and has been considered to evoke inflammation not only to clear invading microbes, but also to cause self-injury that potentially progresses to autoimmune diseases $^{2)}$. Along with studies of TNF $\alpha$ and iNOS producing DCs (Tip-DCs) as putative inflammatory $\mathrm{DCs}^{2)}$, the role of inflammatory DC-produced IL-23 is correlated with autoimmunity rather than with IL-12 production ${ }^{3)}$. While DCs have the capacity to facilitate differentiation of naïve $\mathrm{CD} 4^{+} \mathrm{T}$ cells into a variety of $\mathrm{T}$ helper subsets, it is T helper 17 (Th17) cells that appear to be a unique player inducing granulocytosis and granulomatous inflammation, a histological sign specific for chronic inflamma- tory diseases ${ }^{4}$. In contrast, T helper type 1 (Th1) and type 2 (Th2) cells lead to the production of antigen-specific antibody via $\mathrm{B}$ cells without inflammation. This discovery has markedly advanced our understanding of not only anti-bacterial immunity, but also many inflammatory and autoimmune diseases. However, human studies on the initiation of Th17 by DCs have only advanced slowly because the procedures for the induction of Th17 from human cells are not as well defined as for murine $\mathrm{CD} 4^{+} \mathrm{T}$ cells ${ }^{2)}$. Studies of DCs that promote Th17-immunity substantially remain to be clear. In this review, we focus on studies involving Th17-inducing DCs. In human studies, we summarize reports describing Th17-differentiation from naïve $\mathrm{CD}^{+}{ }^{+} \mathrm{T}$ cells and discuss cases of TGF- $\beta$-dependent or -independent induction of Th17 cells. 


\section{Cytokines Correlated to Promotion of Th17 Response}

IL-23 is essential for IL-23-IL-17 axis inflammation, and the correlation of IL-23 with autoimmunity may relate to the role of IL-23 in regulating IL-17-production as IL-23 was initially thought to be important for the induction of IL-17 ${ }^{7,8}$. However, the finding that the combination of IL- 6 and TGF- $\beta$ induces the expression of a key transcription factor $\mathrm{ROR} \gamma \mathrm{t}$ for IL-17-production $^{5)}$ changed the concept of the IL-23's major role from one of Th17-induction to one of Th17-maintenance. This discovery illustrates the paradigm of Th17-differentiation while TGF- $\beta$ alone induces the expression of Foxp-3, a master gene for regulatory T cells (Treg) ${ }^{5}$. However, Chung et al. described an IL-1dependent TGF- $\beta$-independent pathway in a murine model of experimental autoimmune encephalomyelitis (EAE) ${ }^{6}$. This has again raised a possible role for IL-23 produced by DCs during the initiation of Th17-responses.

\section{Induction of Th17 Cells from Naïve CD4 ${ }^{+} \mathrm{T}$ cells in Mice}

To date, the induction of murine Th17 cells by DCs has been well described through findings of both in vitro and in vivo studies. Murine naïve $\mathrm{CD}^{+}{ }^{+} \mathrm{T}$ cells respond to TCR-signals and are easily differentiated to IL-17-producing cells under conditions in which the effects of IFN- $\gamma$ and IL-4 are inhibited ${ }^{7)}$. In the earlier studies, the induction of antigen-specific Th17 cells by antigen presenting cells (APCs) was proven by the use of OVAspecific TCR transgenic mice. When naïve $\mathrm{CD} 4^{+} \mathrm{T}$ cells were co-cultured with DCs in the presence of IL-23, TCR and ICOS signaling efficiently led to antigen-specific Th17-differentiation ${ }^{8}$. Thereafter, stimulation conditions under which DCs gain a Th17inducing ability were explored along with the mechanism(s) of DC mediated differentiation. Dectin-1 is a receptor for $\beta$-glucan, a component of fungus, which preferentially stimulates DCs to induce Th17 cells as a result of the production of cytokines, including IL-1, IL6, IL-23, and TGF- $\beta$. The Syk-CARD-9 signaling pathway downstream of Dectin-1 was found to be the signal transduction route for DC-mediated Th17-induction ${ }^{9)}$. Furthermore, DCs stimulate T cells through both the TCR and ICOS. These signals synergistically increase IL-21-production in an autocrine manner and increase IL-23 receptor expression. Both IL-21 and IL-23 accelerate the differentiation of Th17 cells through IL-21-IL-23 receptor positive loop stimulation ${ }^{10)}$. Additionally, an IL-1-dependent, IL-6/TGF- $\beta$-independent pathway for Th17-differentiation has been found ${ }^{6}$. This pathway is associated with the activation of transcription factors, IRF-4 and
$\mathrm{ROR} \gamma \mathrm{t}$, and requires IL-23-stimulation ${ }^{6}$. The detailed molecular mechanisms remain to be clarified, as well as how the two individual pathways interact to regulate Th17-immunity. Recently, Lee et al. explored the presumed direct effect of TGF- $\beta$ on Th17differentiation by demonstrating that IL-6 alone can induce Th17differentiation in Stat $6^{-/}$T-bet $^{-/-}$mice, which have impaired Th1and Th2-differentiation ${ }^{10)}$. This suggests that TGF- $\beta$ does not directly affect IL-17-production, but indirectly affects by its inhibitory effects on Th1 and Th2.

The characteristics of DCs that promote antigen specific Th17 cells also have been studied. Bailey et al. showed that a CD $11 b^{+}$ myeloid DC subset accumulates in the central nervous system in EAE models ${ }^{12)}$. This DC subset has the strongest capacity to induce antigen-specific Th17 cells among plasmacytoid DCs and $\mathrm{CD}^{+}$DCs. These data are consistent with inflammatory DCs being derived from myeloid lineages including inflammatory monocytes ${ }^{2)}$.

\section{Induction of Th17 Cells from Naïve CD4+ T cells in Humans}

Unlike naïve murine $\mathrm{CD}^{+} \mathrm{T}$ cells or human memory $\mathrm{T}$ cells, naïve human $\mathrm{CD}^{+}{ }^{+} \mathrm{T}$ cells lack $\mathrm{IL}-23$ receptors; additionally they do not respond to the conditions used in murine experiments that induce conversion to Th17 cells ${ }^{4}$. In order to analyze Th17promoting conditions, we compiled a list of nine reports that study the induction of human Th17 cells in naïve $\mathrm{CD} 4^{+} \mathrm{T}$ cells ${ }^{13-21)}$ (Table 1). Sources of naïve $\mathrm{CD} 4^{+} \mathrm{T}$ cells and the means of $\mathrm{T}$ cell stimulation are summarized. We chose not to include several reports in the list of studies that had negative control naïve $\mathrm{CD}^{+}{ }^{+} \mathrm{T}$ cells which contained IL-17-producing cells (IL-17+< $<1 \%$ ) after PMA/ionomycin treatment. The majority of studies describe the negative control naïve $\mathrm{CD} 4{ }^{+} \mathrm{T}$ cells as being completely negative for IL-17+ cells. Every reported method for Th17-induction is unique. Five reports used naïve $\mathrm{CD}^{+} \mathrm{T}$ cells from peripheral blood mononuclear cells (PBMC), and the others used those from umbilical cord blood (UCB). Naïve $\mathrm{CD}^{+}{ }^{+} \mathrm{T}$ cells from $\mathrm{UCB}$ were more easily converted to Th17 cells than those from PMBC naïve $\mathrm{CD}^{+}{ }^{+} \mathrm{T}_{\text {cells }}{ }^{20)}$. Presumably, the differently sourced naïve $\mathrm{CD} 4^{+}$ $\mathrm{T}$ cells may cause the different responses. For example like human memory $\mathrm{T}$ cells and murine naïve $\mathrm{CD} 4^{+} \mathrm{T}$ cells, naïve human $\mathrm{CD}^{+} \mathrm{T}$ cells from UCB, but not from PBMC, express IL23 receptors ${ }^{4)}$. Interestingly, naïve $\mathrm{CD} 4^{+}$cells were re-stimulated in four of six reports using PBMC ${ }^{13,14,16,17)}$. We demonstrated that treatment with anti-CD3 induced IL-23 receptors on naïve $\mathrm{CD} 4^{+}$ T cells (unpublished data). Furthermore, TGF- $\beta$-independent conversion into Th17 cells was described in a report using 
Table 1 Sources and phenotypes of naïve CD4+ $\mathrm{T}$ cells, its treatments with antigen presenting cells (APCs), antibodiesin, and cytokines, and restimulation of T cells were summarized in the table from data in eight papers describing human Th17-induction from naïve $\mathrm{CD} 4^{+} \mathrm{T}$ cells.

\begin{tabular}{|c|c|c|c|c|c|c|}
\hline \multicolumn{2}{|r|}{ Naïve CD4 T cells } & \multicolumn{4}{|c|}{ Stimulation } & \multirow{2}{*}{ Ref. } \\
\hline Source & Phenotypes & APCs & Treatment with $\mathrm{Ab}$ & Additional Cytokines & Restimulation & \\
\hline PBMC & $\mathrm{CD}^{+}{ }^{+} \mathrm{CD} 45 \mathrm{RO}^{-}$ & $\begin{array}{c}\text { Cell-free, cDC } \\
\text { Monocytes } \\
\text { (LPS)* }\end{array}$ & Anti-CD2/CD3/CD28 & $\begin{array}{l}\text { IL- } 1+\mathrm{IL}-23 \\
\text { No effects of } \\
\text { IL-6+TGF- } \beta\end{array}$ & $\begin{array}{c}\text { Anti-CD2/CD3/CD28 } \\
+ \text { IL-2 }\end{array}$ & 12 \\
\hline PBMC & $\mathrm{CD}^{+}{ }^{+} \mathrm{CD} 45 \mathrm{RA}^{+} \mathrm{CD} 45 \mathrm{RO}^{-}$ & Cell free & Anti-CD3/CD28 & $\begin{array}{c}\mathrm{IL}-1+\mathrm{IL}-6+\mathrm{IL}-23 \\
+\mathrm{TGF}-\beta\end{array}$ & Anti-CD3/CD28 & 13 \\
\hline PBMC & $\mathrm{CD}^{+}{ }^{+} \mathrm{CD} 45 \mathrm{RA}^{+}$ & Skin DC ex vivo & None & IL-15+IL-6+IL-23 & None & 14 \\
\hline PBMC & $\mathrm{CD}^{+}{ }^{+} \mathrm{CD} 45 \mathrm{RA}^{+}$ & $\begin{array}{c}\text { CD1a+moDC } \\
\text { (LPS+R848) }\end{array}$ & None & None & Anti-CD3 & 15 \\
\hline PBMC & $\mathrm{CD}^{+} \mathrm{CD}^{-} 5 \mathrm{RO}^{-}$ & $\begin{array}{l}\text { Monocytes } \\
\text { (PGN)* }\end{array}$ & Anti-CD3 & $\mathrm{IL}-1+\mathrm{IL}-23+\mathrm{PGE}_{2}$ & IL-2 & 16 \\
\hline PBMC & 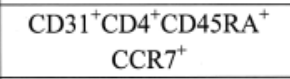 & Cell free & Anti-CD3/CD28 & IL-1 & None & 17 \\
\hline \multirow{2}{*}{ UCB } & $\mathrm{CD}_{161^{+}} \mathrm{CD}^{+}$ & \multirow{2}{*}{ Cell free } & \multirow{2}{*}{ Anti-CD3/CD28 } & \multirow{2}{*}{ IL-1+IL-23 } & \multirow[t]{2}{*}{ None } & \multirow[t]{2}{*}{18} \\
\hline & $\mathrm{CD}^{+}{ }^{+}$Thymocytes & & & & & \\
\hline UCB & $\mathrm{CCR}^{+} \mathrm{CD}^{+}{ }^{+} \mathrm{CD} 45 \mathrm{RO}^{-}$ & Cell free & Anti-CD3/CD28 & $\begin{array}{c}\text { IL-1+IL-6+IL-21+IL-23 } \\
+ \text { TGF- } \beta\end{array}$ & None & 19 \\
\hline UCB & $\mathrm{CD}^{+}{ }^{+} \mathrm{CD} 45 \mathrm{RO}^{-}$ & Cell free & Anti-CD2/CD3/CD28 & $\begin{array}{c}\text { IL-1+IL-6+IL-21+IL-23 } \\
+ \text { TGF- } \beta\end{array}$ & None & 20 \\
\hline
\end{tabular}

Data in the table were sourced from eight papers. PBMC; peripheral blood cells, UCB; umbilical cord blood, DC; dendritic cell, LPS; lipopolysaccharide; PGN; proteoglycan. ( )* indicates stimulatory substances for DCs or monocytes.

$\mathrm{PBMC}^{14)}$. In contrast, re-stimulation was unnecessary for naïve UCB CD4 ${ }^{+} \mathrm{T}$ cells, and in 2 of 3 reports Th17-induction was dependent on TGF- $\beta^{19,20)}$. Interestingly, Cosmi et al. described that CD161, a NK cell specific marker known as NK.1.1 in mice, was specific for human Th17 cells in both UCB and PBMC ${ }^{18)}$. They described Th17 cells as $\mathrm{CD} 161^{+} \mathrm{CD} 4^{+}$cell subsets from the thymus or UCB. However in adult peripheral blood naïve CD4+ T cells, CD161+ ${ }^{+}$Th17 cells are not induced, while CD161+Th17 cells are detected in inflamed tissues of patients with psoriasis. Although precursors of Th17 appear to be different from Th1 or $\mathrm{Th} 2^{4)}$, subsets of naive $\mathrm{CD} 4^{+} \mathrm{T}$ cells that inhibit $\mathrm{Th} 17$ induction may exist; depletion of a minor subset, $\mathrm{CD} 25^{+}$naïve $\mathrm{CD} 4^{+} \mathrm{T}$ cell, can effectively increase Th17-differentiation ${ }^{21}$. Additionally, Th17-induction is enhanced in the presence of prostaglandin $\mathrm{E}_{2}$, which increases expression of IL-23 receptors on T cells. The effects of prostaglandin $\mathrm{E}_{2}$ may be mediated by the inhibition of IFN- $\gamma$, which suppresses Th17-induction ${ }^{17)}$. Along with the IL-23 receptor, expression of IL-1 receptor 1 (IL-1R1) on naïve CD4 T cells also is necessary for Th17-diffentiation. A CD31+ naïve CD4 T cell subset expresses IL-1R1 and differentiates into Th17 cells in the presence of IL- $1 \beta$ under CD3/CD28stimulation, whereas a CD31-IL-1R1- subset does not ${ }^{18)}$. How- ever, naïve CD4 T cells expressing IL-1R 1 after stimulation with IL-7, IL-15, and anti-CD3/CD28 beads do not convert to Th17 cells. These data suggests that IL- $1 \beta$ is necessary, but not sufficient, for naïve human CD4 T cells to differentiate into Th17 cells. The induction of Th17 cells in these listed reports is much lower than that seen in studies using murine cells and experimental models; therefore, additional investigation is needed to further elucidate the complex conditions under which naïve human $\mathrm{CD} 4^{+} \mathrm{T}$ cells undergo significant conversion into Th17 cells.

\section{Studies of human DCs in Induction of Th17}

Some reports have described studies of human Th17-induction by DCs in vitro or in vivo. However, methods using a cellfree system to study the conversion of naïve $\mathrm{CD} 4^{+} \mathrm{T}$ cells into Th17 cells are not always useful for DC-mediated Th17-induction $^{22)}$. Mathers et al. reported that in vitro skin migratory Langerhans cells (LCs) and DCs induced naïve peripheral blood CD4 ${ }^{+}$ $\mathrm{T}$ cells $\left(\mathrm{CD}^{+} \mathrm{CD}^{+} 5 \mathrm{RA}^{+}>90 \%\right)$ to become $\mathrm{IL}-17$-producing cells, which was dependent upon IL-15 and IL-6, but independent of TGF- $\beta$ or IL- $23^{15}$. Conversely, LC-like cells derived from monocytes cultured in the presence of TGF- $\beta$ and GM-CSF were 
dependent upon TGF- $\beta$ for Th17 induction ${ }^{21)}$. According to studies by Trincheri et al. ${ }^{3)}$, stimulation through Dectin-1, TLR-2, and NOD-2, receptors that recognize pathogen associated molecular patterns, converted immature DCs into mature DCs, which promoted Th17-induction. Combined stimulation of monocyte-derived DCs by TLR 4 and TLR7/8 also convert naïve CD4 ${ }^{+} \mathrm{T}$ cells into Th17 cells ${ }^{16}$.

In addition, the condition of monocytes prior to DC-differentiation is important. Previously, we reported that LPS-stimulated DCs derived from monocytes cultured in the presence of GMCSF and TNF (TNF-DC) efficiently induce human Th17 from total $\mathrm{CD}^{+}{ }^{+} \mathrm{T}$ cells ${ }^{24}$. We compared TNF-DCs to DCs derived from monocytes cultured in the presence of GM-CSF and IL-4; TNF-DCs predominantly produced TNF and IL-23 rather than IL-12, and had the capacity to induce Th17 cells (unpublished data).

Zaka et al. provided data on the in vivo characteristics of skin migratory DCs in patients with psoriasis ${ }^{25)}$. They found that CD11 $c^{+}$CD1c-DCs rather than $C D 11 c^{+} C D 1 c^{+} D C s$ (resident DCs) accumulated in the inflamed tissues. The accumulated cells included a Tip-DC population and possessed low levels of macrophage markers, CD14 and CD163. This could be the definitive phenotype specific for human inflammatory DCs, which may be distinct from other subtypes of DCs. However, further in vitro studies using such inflammatory DCs, or Tip-DC-like cells, are necessary.

\section{Concluding Remarks}

The discovery of Th17-immunity represents a major step in our understanding of infectious immunity and autoimmune pathologies. To date, murine experimental disease models have strongly facilitated a better understanding of Th17-immunity; however, studies of human inflammatory DCs have not satisfactorily explained the mechanism(s) by which these DCs initiate and facilitate Th17-immunity. Therefore, to advance our understanding of Th17-immunity in human, a well-defined experimental model using human inflammatory DCs is needed. Human Th17-immunity seems to be normally limited under emergency conditions ${ }^{4}$, and Th17-induction by DCs may be unusual in comparison with former experiments of the induction of Th1 or Th2. According to the reports listed in Table 1, at least two individual pathways, IL-1/IL-23 or IL-6/TGF- $\beta$ dependent Th17-induction, appear to exist in humans as well as in mice; human naïve $\mathrm{CD}^{+} \mathrm{T}$ cells from PBMC appear to require recurrent stimulation to differentiate into Th17 cells. The role of human inflammatory DC biology is complex and investigation of the multiple steps involved in Th17-differentiation may lead to greater understanding of the etiology of autoimmune diseases. While not discussed in this review, understanding the conversion of regulatory T cells into Th17 cells or Th17 cells into Th1 cells is another aspect of Th17-immunity that remains to be elucidated. The regulatory system that controls the balance of these effector $\mathrm{T}$ cells may be influenced by $\mathrm{DCs}^{26}$. Furthermore, the discovery of natural Th17 cells that recognize self-antigens will alter the Th17/Treg balance ${ }^{27)}$. There are likely differences between adult and neonatal Th17-immune responses and this has yet to be fully investigated. In the future, the advance of inflammatory DC biology will contribute to a better understanding of chronic inflammatory diseases and autoimmune diseases, and provide insight for designing targeted therapies or for diagnosis of these diseases.

\section{Acknowledgement}

Thank Professor Kouji. Matsushima (Tokyo University, Tokyo) for Scientific discussion.

\section{References}

1) Banchereau J, Steinman RM: Dendritic cells and the control of immunity. Nature, 392: 245-251, 1998.

2) Zerbina NV, Salazar-Mather TP, Biron CA, Kuziel WA, Pamer EG: TNF/iNOS-producing dendritic cells mediate innate immune defense against bacterial infection: Immunity, 19: 59-70, 2003.

3) Lyakh L, Trincheri G, Provezza, Carra G, Gerosa F: Regulation of interleukin-12/interleukin-23 production and the T-helper 17 response in humans. Immunological Rev., 226: 112-131, 2008.

4) O'Quinn DB, Palmer MT, Lee YK, Weaver CT: Emergence of the Th17 pathway and its role in host defense. Advances in Immunology. (ed. Alt F) Elsever Inc., Vol 99, 2008, pp115-148.

5) Ivanov I, McKenzie BS, Zhou L, Tadokoro CE, Lepelley A, Lafaile JJ, Cua DJ, Littman DR: The orphan nuclear receptor $\mathrm{ROR} \gamma \mathrm{t}$ directs the differentiation program of proinflammatory IL $17^{+} \mathrm{T}$ helper cells. Cell, 126: 1121-1133, 2006.

6) Chung Y, Chang SH, Martinez GJ, Yang MO, Nuriva R, Kang HS, Ma L, Watowich SS, Jetten AM, Tian Q, Dong C: Critical regulation of early Th17 cell differentiation by interleukin-1 signaling. Immunity, 30: 576-587, 2009.

7) Harrington LE, Hatton RD, Mangan PR, Turner H, Murphy TL, Murphy KM, Weaver C: Interleukin 17-producing CD4+ 
effector $\mathrm{T}$ cells develop via a lineage distinct from the $\mathrm{T}$ helper type 1 and 2 lineages. Nat Immunol, 6: 1123-1132, 2005.

8) Park H, Li Z, Yang XO, Chang SH, Nurieva R, Wang Y-H, Wang Y, Hood L, Zhou Z, Tian Q, Dong C: A distinct lineage of CD4 $\mathrm{T}$ cells regulates tissue inflammation by producing interleukin 17. Nat Immunol, 6: 1133-1140, 2005.

9) Reid DM, Gow NR, Brown GD: Pattern recognition: recent insights from Dectin-1. Curr Opin Immunol, 21; 30-37, 2009.

10) Zhou L, Ivanov I, Spolski R, Min R, Shenderov K, Egawa T, Levy DE, Leonard WJ, Littmann: IL-6 programs TH-17 cell differentiation by promoting sequential engagement of the IL-21 and IL-23 pathways. Nat Immunol, 8; 967-974, 2007.

11) Das J, Ren G, Zhang L, Roberts AI, Zhao X, Bothwell ALM, Kaer LV, Shi Y, Das G. Transforming growth facto $b$ is dispensable for the molecular orchestration of Th17 cell differentiation. J Exp Med, 206: 2407-2416, 2009.

12) Bailey SL, Schreiner B, McMahon EJ, Miller SD: CNS myeloid DCs presenting endogenous myelin peptides "preferentially" polarize $\mathrm{CD}^{+}{ }^{+} \mathrm{T}_{\mathrm{H}}-17$ cells in relapsing EAE. Nat Immunol, 8: 172-180, 2007.

13) Wilson N, Bonifare K, Chan JR, McKenzie BS, Blumenschein WM, Mattson JD, Basham B, Smith K, Chen T, Morel F, Lecron J-C, Kastelein RA, Cua DJ, McClanahan TK, Bowman EP, Malefyt RW: Development, cytokine profile and function of human interleukin 17-producing helper T cells. Nat Immunol, 8: 950-956, 2007.

14) Volpe E, Servant N, Zollinger R, Bogiatzi SI, Hupe P, Barillot E, Soumelis V: A critical function for transforming growth factor- $\beta$ interleukin 23 and proinflammatory cytokines in driving and modulating human TH-17 responses. Nat Immunol, 9: 650-656, 2008.

15) Mathers AR, Janelsins BM, Rubin JP, Tkacheva OA, Shufesky WJ, Watkins SC, Morelli AE, Larregina AT: Differential capacity of human cutaneous dendritic cells subsets to initiate Th17 responses. J Immunol, 182: 921-933, 2009.

16) Lombradi V, overtvelt LV, Horiot S, Moingeon P: Human dendritic cells stimulated via TLR7 and/or TLR8 induce the sequential production of IL-10, IFN- $\gamma$, and IL-17A by naïve CD4+ T cells. J Immunol, 182: 3372-3379, 2009.

17) Boniface K, Bak-Jensen KS, Li Y, Blumenschein WM, McGeachy MJ, McClanahan TK McKenzie BS, Kastelein RA, Cua DJ, Malefyt RW: Prostaglandin E2 regulates Th17 cell differentiation and function through cyclic AMP and
EP2/EP4 receptor signaling. J Exp Med, 206: 535-548, 2009.

18) Lee W-W, Kang SW, Choi J, Lee S-H, Eyhon EE: Regulating human Th17 cells via differential expression of IL-1 receptor. Blood, 115: 530-540, 2010.

19) Cosmi L, Palma RD, Santarlasci V, Maggi L, Capone M, Frosali F, Rodolico G, Querici V, Abbate G, Angeli R, Berrino L, Fambrini M, Caproni M, Tonelli F, Lazzeri E, Parronchi P, Liotta F, Maggi E, Romagnami S, Annunziato F: Human interleukin 17-producing cells originate from a CD161 ${ }^{+} \mathrm{CD}^{+}{ }^{+} \mathrm{T}$ cell precursor. J Exp Med, 205: 1903-1916, 2008.

20) Manel N, Unutmaz D, Littman DR: The differentiation of human TH-17 cells requires transforming growth factor- $\beta$ and induction of the nuclear receptor ROR $\gamma \mathrm{t}$. Nat Immunol, 9: 641-649, 2008.

21) Yang L, Anderson DE, Baecher-Allan C, Hastings WD, Bettelli E, Oukka M, Kuchroo VK, Hafler DA: IL-21 and TGF- $\beta$ are required for differentiation of human TH17 cells. Nature, 454: 350-352, 2008.

22) Duraisingham SS, Hornig J, Gotch F, Patterson S: TLRstimulated CD34 stem cell-derived human skin-like and monocyte-derived dendritic cells fail to induce Th17 polariztion of naïve T cells but do stimulate Th1 and Th17 memory responses. J Immunol, 183: 2242-2251, 183, 2009.

23) Aliahamadi E, Gramlich R, Grutzkau A, Hitzler M, Ktuger M, Baumgrass R, Schreuner M, Wittig B, Wanner R, Peir M: TLR2-activated human langerhans cell promote Th17 polarization via IL-1b, TGF- $\beta$ and IL-23. Eur Immunol, 39: 1221-1230, 2009.

24) Iwamoto $S$, Iwai $S$, Tsujiyama $K$, Kurahashi $C$, Takeshita K, Naoe M, Masunaga A, Ogawa Y, Oguchi K, Miyazaki A: TNF-a derived human $\mathrm{CD} 14^{+}$monocytes to differentiate into $\mathrm{CD} 70^{+}$dendritic cells evoking $\mathrm{Th} 1$ and $\mathrm{Th} 17$ responses. J Immunol, 179: 1449-1457, 2007.

25) Zaba LC, Fuentes-Duculan J, Eungdamorng NJ, Abello MV, Novitskaya I, Pierson KC, Gonzalez J, Krueger LG, Lowes MA: Psoriasis is characterized by accumulation of immunostimulatory and Th1/Th17 cell-polarizing Myeloid dendritic cells. J Invest Dermatol, 129: 79-88, 2008.

26) Zhou L, Chong MMW, Littman DR: Plasticity of $\mathrm{CD}^{+} \mathrm{T}$ cell lineage differentiation. Immunity, 30: 646-655, 2009.

27) Marks BR, Nowyred HN, Choi J-Y, Poholek AC, Odegard JM, Flavell RA, Craft J: Thymic self-reactive selects natural interleukin 17-producing $\mathrm{T}$ cells that can regulate peripheral inflammation. Nat Immunol, 10: 1125-1132, 2009. 